AC 2001-660: Materials Chemistry for Freshmen

Elliot Douglas, University of Florida

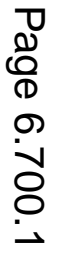




\title{
Materials Chemistry for Freshmen
}

\author{
Elliot P. Douglas \\ University of Florida
}

\begin{abstract}
We have developed a new Materials Chemistry course for freshmen with the goal of improving retention in the engineering program. This Materials Chemistry course is fundamentally different from other introductory materials courses in that it does not cover the standard introductory materials curriculum (diffusion, strengthening mechanisms, eutectic phase diagrams, etc.). Rather, its goal is to teach engineering applications of fundamental chemistry concepts. This course consists of four basic units: atomic, molecular and supermolecular structures; synthesis and processing; stability of materials; and biological materials. Each of these units consists of topics designed to show how fundamental concepts in chemistry can be applied to engineering problems. For example, liquid crystal display technology is used to teach the concept of molecular shape. The course also contains a laboratory section. This paper will describe the detailed contents of the course and its relation to the engineering curriculum.
\end{abstract}

\section{Introduction}

There is a growing awareness of the need to introduce freshmen, who have declared engineering as a major, to engineering concepts. In the traditional curriculum, the freshman year is devoted to sciences and humanities, with little, if any, engineering content. In response, a number of approaches have been developed, including engineering survey courses, ${ }^{1}$ freshman design courses, ${ }^{2-6}$ and courses that focus on basic skills required of engineering students. ${ }^{7}$

Of particular interest to this paper are efforts to created integrated curricula in the freshman year. ${ }^{8}$ These curricula attempt to integrate basic science (e.g. chemistry, physics, math) with engineering. The approach may involve individual courses, blocks of courses, or an entire freshman curriculum. Results suggest that these approaches are successful, resulting in higher retention and higher grade point averages. The attractiveness of this approach with regards to materials engineering has been noted in a report from the National Science Foundation, ${ }^{9}$ which concludes that "the attractiveness of chemistry and physics...could be enhanced by greater emphasis on materials-related topics which would help students better relate their studies to the 'real world'."

With this in mind, we have developed a new course, titled Materials Chemistry. The goal of this course is to provide engineering applications of basic chemistry concepts at the freshman level. This paper describes the role of this course within the engineering curriculum at the University of Florida and a description of the course content.

Proceedings of the 2001 American Society for Engineering Education Annual Conference \& Exposition Copyright (C) 2001, American Society for Engineering Education 


\section{Role of the Course}

The first year of the engineering curriculum at the University of Florida is completely devoted to satisfying general science, writing, and humanities requirements. None of the official tracking for any engineering program contains an engineering course in the freshman year. The first year courses for students majoring in Materials Science and Engineering are provided in Table 1 as an example. There are only two possible means for a student to obtain engineering content in the first year. Some students opt to take Introduction to Engineering. This is a 1 credit course in which students visit one department a week to learn about that particular type of engineering discipline. This course is primarily for students to familiarize themselves with different types of engineering, and does not contain any rigorous technical content. Students who are able to place out of some of the freshman science courses may choose to take introductory engineering courses in their place (e.g. Statics, Circuits, etc.). In general, however, students who are admitted to the College of Engineering do not have any exposure to engineering content in their freshman year. Thus, the Materials Chemistry course was developed to fill this need.

Table 1. Freshman year courses for students majoring in materials science and engineering.

\begin{tabular}{|c|l|}
\hline Semester & \multicolumn{1}{|c|}{ Course* $^{*}$} \\
\hline \multirow{5}{*}{1} & Social and Behavioral Sciences (3) \\
\cline { 2 - 3 } & Humanities (3) \\
\cline { 2 - 2 } & Analytical Geometry and Calculus 1 (4) \\
\cline { 2 - 2 } & Chemistry 1 (3) \\
\cline { 2 - 2 } & Chemistry 1 Lab (1) \\
\hline \multirow{5}{*}{2} & Humanities (3) \\
\cline { 2 - 2 } & Technical Writing (3) \\
\cline { 2 - 2 } & Analytical Geometry and Calculus 2 (4) \\
\cline { 2 - 2 } & Chemistry 2 (3) \\
\cline { 2 - 2 } & Chemistry 2 Lab (1) \\
\hline
\end{tabular}

*Credit hours are shown in parentheses.

Another important consideration in developing this course was the effect it would have on transfers from community colleges. The articulation agreement between the State University System and the Florida Community College System states that equivalent courses must be available at the universities and the community colleges, allowing transfers to complete their degrees in the same amount of time as students who enter the university as freshmen. Thus, it was important that the Materials Chemistry course include similar content to the general chemistry course available at the community colleges. At the same time, an introductory course in materials science and engineering exists at the junior level at the University of Florida. This course is one of the engineering core courses, and thus it was also important that the Materials Chemistry course not include content already covered by this existing course. A summary of the topics included in the junior level course, as taught by the author, is given in Table 2. From this consideration it is evident that our Materials Chemistry course is of necessity different from

Proceedings of the 2001 American Society for Engineering Education Annual Conference \& Exposition Copyright (O) 2001, American Society for Engineering Education 
other, similar courses, such as the Solid-State Chemistry course at MIT. At MIT, for example, Solid-State Chemistry fills the dual roles of general chemistry and introduction to materials, and thus includes many of the topics listed in Table 2.

Finally, we considered the relationship of the Materials Chemistry course to the general chemistry curriculum. All engineering students are required to take Chemistry 1 with lab, and some students (including those majoring in Materials Science and Engineering) are required to take Chemistry 2 with lab. While it might be desirable to use Materials Chemistry in place of Chemistry 1 for maximum impact, it was decided to develop Materials Chemistry as an option for Chemistry 2. This was because the application of chemistry to engineering would require students to have some knowledge of basic chemistry principles. Thus, it was felt appropriate for students to first learn these principles in a general chemistry course.

Table 2. Content of junior level introductory materials course.

\begin{tabular}{|c|c|}
\hline Lesson Number & Topic \\
\hline 1 & Introduction \\
\hline 2 & Bonding \\
\hline $3-8$ & Crystals Structures and Defects \\
\hline 9 & Polymers \\
\hline $10-11$ & Diffusion \\
\hline $12-13$ & Strength and Strengthening Mechanisms \\
\hline $14-16$ & Phase Diagrams \\
\hline $17-20$ & Polymer Transitions and Properties \\
\hline $21-23$ & Mechanical Properties \\
\hline $24-26$ & Materials-Environment Interactions \\
\hline $27-30$ & Electrical Properties \\
\hline $31-33$ & Applications of Materials Science and Engineering \\
\hline $34-36$ & \\
\hline $37-38$ &
\end{tabular}

\section{Classroom Content}

The general content of the course was determined by a committee of faculty from the Department of Materials Science and Engineering, with the author as chair. The content of the course was designed to highlight important themes in materials chemistry. As such, the course is divided into four major sections. These sections, along with their descriptions are:

Atomic, Molecular, and Supermolecular Structures: Types of bonding between atoms, molecular structures of materials (e.g. polymers), and how atoms and molecules are arranged into larger structures (e.g. crystals). The role of bonding and structure in determining the properties of materials (e.g. density, thermal expansion, stiffness, conductivity). 
Synthesis and Processing: How materials are made. Emphasis on thermodynamics (the energies involved) and kinetics (how fast things happen), as well as the interplay between thermodynamics and kinetics in determining whether processes are practical. Examples include chemical reactions such as catalysis to form polymers, crystallization, and phase diagrams.

Stability of Materials: Reactions of materials in service environments, including examples of when enhanced stability may be desirable or undesirable. Specific topics include corrosion reactions, degradation of polymers, issues in recycling and disposal of materials, biodegradation.

Biological Materials: The chemistry of life, such as the structures of commonly referred to biological molecules (e.g. proteins, sugars, lipids, cholesterol, saturated fats, polysaccharides, DNA, antibodies). The kinetics of biological processes (enzymes as catalysts). The compatibility of materials used for medical devices and implants. The chemistry associated with genetic engineering, which is used for both pharmaceutical applications, as well as for modifying the genetic codes of life.

Table 3. List of chemistry concepts and the corresponding engineering examples.

\begin{tabular}{|l|l|}
\hline Topic & Examples \\
\hline Bonding & $\begin{array}{l}\text { Liquid crystals (molecular shape) } \\
\text { Melting temperature, polymer glass transition (secondary bonds) } \\
\text { Mechanical properties (bond type and strength) }\end{array}$ \\
\hline Molecules and crystals & $\begin{array}{l}\text { Organic compounds } \\
\text { Polymers } \\
\text { Inorganic materials } \\
\text { Density (crystal structures) } \\
\text { DNA }\end{array}$ \\
\hline Enthalpies of bond formation & Free radical polymerization \\
\hline Equilibrium reactions & Condensation polymerization \\
\hline Acids and bases & Phosphate mining \\
\hline Thermodynamics & $\begin{array}{l}\text { Polymer ceiling temperature (depolymerization) } \\
\text { Solubility } \\
\text { Phase diagrams (including technologically relevant metallic } \\
\text { phase diagrams) }\end{array}$ \\
\hline Kinetics & $\begin{array}{l}\text { Crystallization } \\
\text { Enzymes }\end{array}$ \\
\hline Electrochemistry & $\begin{array}{l}\text { Corrosion } \\
\text { Batteries }\end{array}$ \\
\hline
\end{tabular}

After the work of the committee, the author was assigned to teach this course. With the above themes in mind, the detailed content of each lesson was planned. Table 3 provides a list of covered topics, and the engineering examples used. Note that these are not necessarily given in 
order of their presentation throughout the semester. While it is not possible to describe all lessons in detail, two examples will provide an overview of the flavor of the course.

In Chemistry 1, students learn the Valence Shell Electron Pair Repulsion (VSPER) model for determining molecular geometry. In the Atomic, Molecular, and Supermolecular Structures section of Materials Chemistry, this model is applied to understanding the molecular requirements for liquid crystallinity. The lesson begins with a brief description of the operation of liquid crystal displays and the definition of a liquid crystal. Two molecules are shown (see Figure 1), and the students are told that one is liquid crystalline and one is not. The VSPER model is reviewed and applied to these molecules to show that the molecule containing a methylene central unit (part a of Figure 1) is bent, while the other molecule is straight. Additionally, the concept of rotational barriers is introduced and also applied to these molecules to show that the methylene containing molecule is flexible, while the other remains rigid. This lesson highlights two important points regarding the Materials Chemistry course. First is the application of basic concepts (VSPER) to important engineering applications (liquid crystal displays). Second is the approach of teaching material on an "as-needed" basis. In the traditional chemistry curriculum the concept of rotational barriers is not typically taught until organic chemistry, a course which few engineering students will take. However, the concept is important for understanding how to design materials to be liquid crystals, and thus it is included in this course.

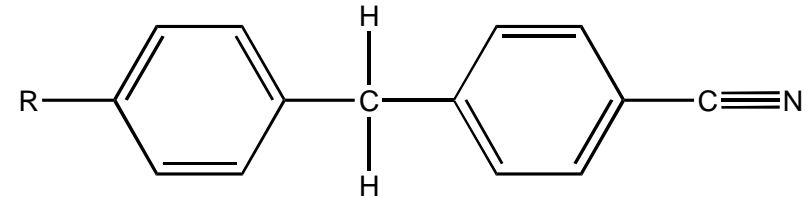

(a)

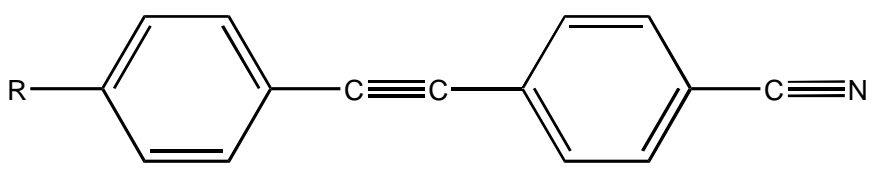

(b)

Figure 1: Molecules used in the molecular geometry lesson: (a) non-liquid crystalline and (b) liquid crystalline.

Another lesson example from Materials Chemistry comes in the lessons on corrosion which are part of the Stability of Materials section of the course. In the general chemistry sequence, students are not exposed to electrochemistry until Chemistry 2. Therefore, in this case the role of Materials Chemistry is to actually teach the basic concepts, as well as show their application. Thus, the lessons consist of the fundamentals of electrochemistry and their application to both corrosion and batteries. It should be noted that corrosion is also part of the junior level introductory materials course (see Table 2). The distinction is that Materials Chemistry focuses on the chemical aspects (e.g. oxidation-reduction reactions, cell potentials), while the junior level

Proceedings of the 2001 American Society for Engineering Education Annual Conference \& Exposition Copyright (C) 2001, American Society for Engineering Education 
course focuses more on practical aspects of corrosion (e.g. types of corrosion, corrosion prevention). While there is some overlap (e.g. the galvanic series), the overall goal of each course is distinct.

\section{Laboratories}

Traditionally, general chemistry laboratories are seen to suffer from a "cookbook" approach. There is some effort to change that by creating laboratory activities that are more open-ended, allowing the students to reach their own conclusions about the data that is collected. ${ }^{10}$ In some cases, the students are only given the overall goal of the lab, and must develop the experimental procedure on their own. This approach is more akin to the engineering experience, and thus is the approach used in developing the laboratories.

A partial list of laboratories is given in Table 4. The laboratories are designed to supplement the classroom material. In some cases the labs show the application of material learned in the classroom, in others the labs go beyond the classroom material, and in some cases the labs illustrate important points ahead of the classroom presentation so that students have had a concrete experience to which they can then relate the abstract concepts. In addition, some of the labs are designed to be open-ended, as described above. One interesting point about the laboratories is that they are all conducted on open benches. This was a matter of practicality; since hood space is not available for all students, experiments were designed that would not require hoods.

Table 4. Partial list of laboratories.

\begin{tabular}{|l|l|}
\hline Laboratory & Chemistry or Engineering Concept \\
\hline Searching the Scientific Literature & identifying prior work, reporting results \\
\hline Density & crystal structures, statistics \\
\hline Mechanical Properties & bonding \\
\hline Copolymer Composition & acid/base titration \\
\hline PET Crystallization & kinetics \\
\hline Corrosion & electrochemistry \\
\hline
\end{tabular}

Again, only two examples of the laboratories are described here in detail. One of the first labs is on density measurement. Students are provided with a metal sample, and simply asked to determine its density. It is presumed that students will decide to measure its volume with a ruler and its mass on a balance. After this set of experiments, Archimedes Principle is explained, and the students utilize that technique to measure density. For both procedures, the students are required to make multiple measurements. In their report, the students are asked to compare the different techniques to each other and to the accepted value, using appropriate statistics, and make a judgment as to which technique should be preferred. They also are asked to assess the source of any errors in the techniques. The lab is also related to classroom material, since one of the lectures deals with crystal structures and calculation of density. The students are asked in the

Proceedings of the 2001 American Society for Engineering Education Annual Conference \& Exposition Copyright (C) 2001, American Society for Engineering Education 
lab to calculate the theoretical density of the material, and compare it with the three experimental values (their own and the accepted value). Finally it should be noted that this experiment is not conducted in isolation from the rest of the laboratories. The students are asked to use density measurements to determine crystallinity in the PET Crystallization lab.

Another laboratory is on the topic of corrosion. In this lab the students must assess the factors that govern the rate of galvanic corrosion. An iron nail is wrapped with a strip of another metal (e.g. zinc) to create a galvanic couple, and the couple is placed in a test tube. Students are provided with solutions of different substances (e.g. acid, base, salt) at various concentrations which they can add to the test tube. They also have the ability to change the temperature at which the reaction occurs. Students record visual observations at appropriate time intervals to assess the rate of corrosion. It is up to the students to decide how they will adjust the different variables to determine how the different factors may affect corrosion rate.

\section{Conclusions}

The Materials Chemistry course described here provides an approach to introducing freshmen to engineering concepts. Its goal is to demonstrate the engineering applications of basic chemistry concepts. While the concept is attractive, a number of questions remain. Is it an effective approach to introducing engineering to freshmen? Will it improve retention of freshmen in the engineering programs? In the future we plan to analyze the experiences of students who take this course to answer these questions.

References

1. Hoit, Marc and Matthew Ohland, "The Impact of a Discipline-Based Introduction to Engineering Course on Improvin Retention", Journal of Engineering Education, vol. 87, no. 1, 1998, pp. 79-85

2. Milano, Geraldine B., Richard Parker, and George Pincus, "A Freshman Design Experience: Retention and Motivation”, Proceedings, ASEE Annual Conference, ASEE, 1996

3. Rizkalla, Maher E., Charles F. Yokomoto, and Carol L. OLoughlin, "A New Design-Oriented Approach for Freshman Engineering”, Proceedings, ASEE Annual Conference, ASEE, 1996

4. Courter, Sandra Shaw, Lymon Lyons, Susan Bolyard Millar, and Andrea Bailey, "Student Outcomes and Experiences in a Freshman Engineering Design Course", Proceedings, ASEE Annual Conference, ASEE, 1996

5. Hiles, Kirk E., “A Project-Based Freshman Engineering Design Experience - FIRST”, Proceedings, ASEE Annual Conference, ASEE, 1997

6. Kallas, M. Nabil, Renata Engel, and Dhundy Sathianathan, "Teaching Design Skills in the Freshman Engineering Curriculum”, Proceedings, ASEE Annual Conference, ASEE, 1996

7. Gunn, Craig James, "Addressing the Freshman Need for an Engineering Experience", Proceedings, ASEE Annual Conference, ASEE, 1996

Proceedings of the 2001 American Society for Engineering Education Annual Conference \& Exposition Copyright (C) 2001, American Society for Engineering Education 
8. Al-Holou, Nizar, Nihat M. Bilgutay, Carlos Corleto, John T. Demel, Richard Felder, Karen Frair, Jeffrey E. Froyd, Marc Hoit, Jim Morgan, and David L. Wells, "First-Year Integrated Curricula: Design Alternatives and Examples", Journal of Engineering Education, vol. 88, no. 4, 1999, pp. 435-448

9. Report on the National Science Foundation Undergraduate Curriculum Development Workshop in Materials, NSF, October 11-13, 1989

10. Lamba, Ram, Jesus Monzón, George Bodner, George Lisensky, Brock Spencer, and Laura Parmentier, Discovering Chemistry, John Wiley and Sons, 1997

\section{ELLIOT P. DOUGLAS}

Elliot P. Douglas is an Ass't. Professor of Materials Science and Eng. at the University of Florida. He received two bachelor's degrees from MIT in 1988, one in Materials Science and Engineering and one in Humanities and Engineering. He received his Ph.D. from the University of Massachusetts at Amherst in 1992 in Polymer Science and Engineering. His teaching interests are in faculty development and engineering applications of basic science.

Proceedings of the 2001 American Society for Engineering Education Annual Conference \& Exposition Copyright (C) 2001, American Society for Engineering Education 